Vol. 7(11), pp. 162-167, November 2015

DOI: $10.5897 /$ J NM2015.0162

Article Number: D56B18155733

ISSN 2141-2456

Copyright $\odot 2015$

Author(s) retain the copyright of this a ricle

International Journal of Nursing

http:// www.academic joumals.org/ I NM

\title{
The effectiveness of the intervention of "Sehat Umakna Sehat Anakna" towards improving the behavior, knowledge and attitude of pregnant mother towards maternal and neonatal care in Mandailing Natal, Sumatera Utara, Indonesia
}

\author{
Siti Saidah Nasution*, Badaruddin, Guslihan Dasatjipta and Zulhaida Lubis \\ Doctoral Program, Faculty of Public Health, University of Sumatera Utara, JI. Prof. Maas, Kampus USU, \\ Medan 20155, Indonesia.
}

Received 13 February, 2015; Accepted 31 August, 2015

\begin{abstract}
Behavior that can influence the status of public health cannot be separated from the culture of the community itself and family habit in a treatment. Mandailing Natal (Madina) district is one of the regions with high maternal and child mortality rate, and the life of the community is very much influenced by their tradition and culture. This is a quasi-experimental study with an intervention in the form of involving the community members in health care through the establishment of health awareness community team "Sehat Umakna Sehat Anakna". The population of this study includes all the pregnant mothers in Madina district, and $\mathbf{7 8}$ of them were selected for this study through purposive sampling technique. The data for this study were obtained through questionnaire distribution and interviews. The result of this study showed that the intervention done had a significant influence on the health status with behaviour, knowledge and attitude ( $p$ value $<0.001$ comprising knowledge with $p=0.001$.) The conclusion is that, intervention has brought an impact in improving the status of public health especially for mothers and their babies through health care. The government and health workers should involve the community members in the implementation of health program and pay attention to the local culture.
\end{abstract}

Key words: Behavior, knowledge, attitude, culture of community.

\section{INTRODUCTION}

One of the purspose of achievements of the government in the field of health, which is in line with the millennium development goals (MDGs) program for 2015, is to improve the status of mother and child health through

*Comespond ing author. E-mail: saidah.nasution@ya hoo.com.

Author(s) agree that this article remain permanently open access under the terms of the Creative CommonsAttribution License 4.0 Intemational License 
minimizing the maternal and infant mortality rate. The acceleration of minimizing maternal and infant mortality rate must involve all aspects, such as medical, health services management and active role of community aspects (Depkes, 2002).

Health status will be determined by the condition commencing from pregnancy up to the delivery and it is related to the behavior of mother and family in daily health care. Mandailing Natal (Madina) district is one of the districts of the province of Sumatera Utara with the maternal and infant mortality rate which is still higher compared to the other districts of other provinces. Madina district is also one of the districts that focused on the acceleration of the MDGs achievement program, especially the expanding maternal and neonatal survival (EMAS) program for mother and infant. Besides, the lives of the people living in Madina community is still very much influenced by family tradition and socio-cultural habits adopted and practiced for generations. To date, based on the aforementioned assumption and phenomenon, intervention compulsorily needed to be performed to improve the public health status through community empowerment program. The intervention implemented was the establishment of a model through the socio-cultural based involvement and active role of the community in improving maternal health behavior, especially in the form of action taken in health care during pregnancy, delivery, post-partum and baby care.

Health status is a dynamic and individual condition influenced by personal and environmental factors. There are 4 factors that influences people's health status; these factors are heredity, health care, environment and behavior. Of the 4 factors, the ones with a significant role in the degree of people's health are the environmental factor $(45 \%)$ and behavioral factor $(30 \%)$ (Saunders et al., 2005). High maternal mortality rate related to pregnancy and delivery in the community is influenced by tradition with 3 "late" conditions (too late to take decision, too late to arrive in the venue of medical services and too late to get adequate medical assistance) and 4 "too" conditions (too old, too young, too many and too close to birth distance) (Depkes, 2002). The application of theory with community empowerment in preventing and minimizing the maternal and child morbidity and mortality rate is an important thing that must be paid attention to, especially the problem influenced by socio-cultural practices (Bobak et al., 2005).

Culture is a set of guidelines that are inherited by individuals as members of a particular community, and how to relate to others (Nasution, 2005). Ritonga (2002), argued that several concepts are often used as the basis of cultural distinction, character, basic personality, perception, concept of time, thought, language, values, behaviors (norms, rules, properties) and grouping as well as social relationships. Most of the human actions and behaviors is based on the values of what is considered bad, good and neutral, although this way of grouping is different from one tribe and culture to the others.

Batak community in general includes the Mandailing who are still on the traditional level in terms of essence of life have their common main purpose of life such as hamoraon (wealth), hagebeon (having many children), and hasangapon (the have) (Nasution, 2005). Sociocultural factor plays an important role in understanding the attitude and behavior to respond to pregnancy, delivery, and the treatment of the mother and her baby. Some part of cultural view on these issues has been inherited from generation to generation in the culture of the given community (Meutia, 1998).

\section{METHODOLOGY}

This is a quasi-experimental study with pretest-posttest non equivalent group design conducted in two groups, namely intervention group and control group. Intervention group was conducted in two stages; the first stage was to establish the health awarteness community team with program "Sehat Umakna Sehat Anakna" and the second stage was to continue the intervention to the respondents, comprising pregnant mothers. The members of the health awareness community team were 28 persons representing community figures, adat figures, health cadres and village apparatuses who were believe to be able to be the role model in the life of the community.

Based on the concensus result, the health awareness community team established in Mandailing Natal (Madina) district will be involved in the program to improve the status of mother and child health. The team members were then trained for one month, and were educated on topics related to antenatal care, delivery, postpartum and neonates based on the perception and culture of local community. After the training, the team was assigned to provide the extension to the 39 pregnant mothers who were in the intervention group, while the other 39 pregnant mothers who were in the control group extension were not given any extension. The extension materials were delivered in local language and in accordance with the understanding of the mothers.

Data were obtained through questionnaire distribution and interviews conducted before and after the intervention was carried out. The data obtained were analyzed through Paired-t test (pretest and posttest) by the group of health awareness team. The independent- $t$ test done to the respondents comprising the pregnant mothers belonged to both intervention and control groups. The statistical test was applied at $\alpha=0.05$.

\section{RESULT}

The members of health awareness community team who had been trained were 28 persons. There was a difference between the knowledge and attitude of the members of health awareness community team before and after the training as shown in Table 1. The characteristics of respondents (pregnant mothers) are presented in Table 2.

Based on Table 2, it was found out that in general the pregnant mothers belonged to the high risk range in reproductive health either in the intervention or control groups. There was a difference between mother's behaviour, such as the knowledge and attitude of the 
Table 1. The difference of the score of pretest and postest of the knowledge and attitude of the members of Health Awareness Community Team $(\mathrm{N}=28)$.

\begin{tabular}{|c|c|c|c|c|c|}
\hline \multirow{2}{*}{ Assessed items } & \multicolumn{2}{|c|}{ Before } & \multicolumn{2}{|c|}{ After } & \multirow{2}{*}{$p$} \\
\hline & $\mathbf{N}$ & $\%$ & $\mathbf{N}$ & $\%$ & \\
\hline \multicolumn{6}{|l|}{ Knowledge } \\
\hline Good & 4 & 14.3 & 10 & 35.7 & \multirow{2}{*}{0.031} \\
\hline Poor & 24 & 85.7 & 18 & 64.3 & \\
\hline \multicolumn{6}{|l|}{ Attitude } \\
\hline Good & 6 & 21.4 & 16 & 56.1 & \multirow{2}{*}{0.002} \\
\hline Poor & 22 & 78.6 & 12 & 42.9 & \\
\hline
\end{tabular}

*Note: $<0.05$.

Table 2. Frequency distribution characteristics of respondents of pregnant women $(N=78)$.

\begin{tabular}{|c|c|c|c|c|}
\hline \multirow{2}{*}{ Variable } & \multicolumn{2}{|c|}{ Intervension } & \multicolumn{2}{|c|}{ Control } \\
\hline & $\mathbf{N}$ & $\%$ & $\mathbf{N}$ & $\%$ \\
\hline \multicolumn{5}{|l|}{ Age } \\
\hline$>20$ years & 7 & 17.94 & 5 & 12.82 \\
\hline 20-35 years & 12 & 30.76 & 11 & 28.20 \\
\hline$>35$ years & 21 & 55.26 & 22 & 56.41 \\
\hline \multicolumn{5}{|l|}{ Number of children } \\
\hline 1 & 4 & 10.2 & 3 & 7.69 \\
\hline $2-3$ & 5 & 12.8 & 4 & 10.25 \\
\hline$>3$ & 30 & 76.9 & 32 & 82.05 \\
\hline \multicolumn{5}{|l|}{ Distance born } \\
\hline$<2$ years & 25 & 64.10 & 26 & 66.66 \\
\hline$>2$ years & 14 & 35.8 & 13 & 33.33 \\
\hline \multicolumn{5}{|l|}{ Education } \\
\hline No school & 8 & 10.26 & 9 & 11.54 \\
\hline Elementary school & 16 & 20.51 & 14 & 17.95 \\
\hline Junior high school & 6 & 7.69 & 5 & 6.41 \\
\hline Senior high School & 5 & 6.41 & 6 & 7.69 \\
\hline Undergoadrate & 4 & 5.13 & 5 & 6.41 \\
\hline \multicolumn{5}{|l|}{ Working } \\
\hline Peasant/Laborers & 6 & 16.4 & 4 & 10.3 \\
\hline Entrepreneur & 2 & 5.1 & 5 & 12.8 \\
\hline Goverment & 2 & 5.1 & 3 & 7.7 \\
\hline Other & 29 & 74.4 & 27 & 69.2 \\
\hline \multicolumn{5}{|l|}{ Income } \\
\hline$<$ Rp. 700.000 & 10 & 25.6 & 6 & 15.4 \\
\hline Rp. $700.000-2.000 .000$ & 23 & 59.0 & 23 & 59.0 \\
\hline$>$ Rp. 2.000 .000 & 6 & 15.4 & 10 & 25.6 \\
\hline \multicolumn{5}{|l|}{ Decition making } \\
\hline Husband & 32 & 82.1 & 31 & 79.5 \\
\hline Wife & 2 & 5.1 & 1 & 2.6 \\
\hline Husband and wife & 4 & 10.3 & 4 & 10.3 \\
\hline Other family members & 1 & 2.6 & 3 & 7.7 \\
\hline Total & - & 78 & - & \\
\hline
\end{tabular}


Table 3. Differences in mother's behaviour: knowledge in the intervention group and the control group $(\mathrm{N}=78)$.

\begin{tabular}{|c|c|c|c|c|c|c|c|c|c|}
\hline \multirow{3}{*}{ Behaviour } & \multicolumn{4}{|c|}{ Intervention } & \multicolumn{4}{|c|}{ Control } & \multirow{3}{*}{$p$} \\
\hline & \multicolumn{2}{|c|}{ Before } & \multicolumn{2}{|c|}{ After } & \multicolumn{2}{|c|}{ Before } & \multicolumn{2}{|c|}{ After } & \\
\hline & $\mathrm{N}$ & $\%$ & $\mathbf{N}$ & $\%$ & $\mathrm{~N}$ & $\%$ & $\mathrm{~N}$ & $\%$ & \\
\hline Knowledge & & & & & & & & & 0001 \\
\hline Good & 23 & 59 & 34 & 87.2 & 27 & 69.2 & 64.1 & - & 0.001 \\
\hline Poor & 16 & 41 & 5 & 12.8 & 12 & 30.8 & 35.9 & - & \\
\hline
\end{tabular}

${ }^{*} \mathrm{P}<0.05$.

Table 4. Differences in mother's behaviour: attitude in the intervention group and control group $(\mathrm{N}=78)$.

\begin{tabular}{|c|c|c|c|c|c|c|c|c|c|}
\hline \multirow{3}{*}{ Behaviour } & \multicolumn{4}{|c|}{ Intervention } & \multicolumn{4}{|c|}{ Control } & \multirow{3}{*}{$P$} \\
\hline & \multicolumn{2}{|c|}{ Before } & \multicolumn{2}{|c|}{ After } & \multicolumn{2}{|c|}{ Before } & \multicolumn{2}{|c|}{ After } & \\
\hline & $\mathbf{N}$ & $\%$ & $N$ & $\%$ & $\mathbf{N}$ & $\%$ & $\mathbf{N}$ & $\%$ & \\
\hline \multicolumn{10}{|l|}{ Attitude } \\
\hline Good & 25 & 64.1 & 34 & 87.2 & 27 & 69.2 & 64 & 69.2 & \multirow{2}{*}{0.001} \\
\hline Poor & 14 & 35.9 & 5 & 12,8 & 12 & 30.8 & 12 & 30.8 & \\
\hline
\end{tabular}

${ }^{*} \mathrm{P}<0.05$.

intervention and control groups as shown in Table 3.

Based on Tables 3 and 4, there are several influences of intervention on several variables of health status such as behaviour of mother pregnant knowledge and attitude.

\section{DISCUSSION}

In general, the result of this study showed that intervention had influence on the improvement of maternal and neonatal health status with impact behaviour: knowledge and attitude with pregnant mother, community team in Mandailing Natal (Madina) district.

According to Notoatmojo (2003), education, experience, culture and belief are the factors influencing the knowledge and attitude of people. Besides, the knowledge has influence on the level of awareness in solving health problems, medication, disease prevention and treatment. The existence of a tradition in the community such as cultural views about pregnancy and birth, morbidity, and mortality in every area varies according to the existing beliefs and customs (Bobak et al., 2005). Various diseases and cases that caused the maternal and infant morbidity and mortality are closely related to the perception of culture that is not conducive to health, and this condition is still widely found in various places in Indonesia, especially in areas that are still dominated by local customs (Swasono, 1998). Changes in the public behavior that has become their daily habit and belief embraced from generation to generation is a difficult thing to do without involving the person who actively plays a role in the given culture. The implementation of intervention in this study directly involved community leader in capacity as a role model for the people in the area (Friedman, 1998).

This agrees with the notion that social condition is a condition or position socially deliberately arranged that a person is put at a particular position in the social structure (Soekanto,1997). The implementation of intervention by involving community members and paying attention to the social culture of local community in improving behavior especially the behavior of pregnant mothers in antenatal care, delivery, post-partum and neonates is an appropriate and effective action in supporting the program to achieve more optimal degree of public health status. This fits with the role and function of the health workers who facilitated the involvement of family and community members in assisting the individual and families in order to be able to make decisions, to help families gain a positive experience in accordance with their expectations, to overcome the problems in maternal and infant care, and the interaction among them through an educational program known as a family-centered maternity care (May and Mahlmeister, 1990).

The intervention was done through community empowerment, by making the community members independent through the materialization of the potential ability owned in antenatal care, delivery, post-partum and neonates. This intervention can be gotten by paying attention to the social culture of the local community members, involving local community figures and local adat leaders. Intervention was carried out by activating the role of community members who play an important role in influencing beliefs, traditions and customs. This is in line with the concept saying that community empowerment is an attempt to enhance the dignity of society that in the present conditions are not able to 
escape from the trap of poverty, ignorance and backwardness.

Empowerment is an attempt to make the community members independent through the materialization of the potential ability owned. One of the effective strategies in improving health status such as behaviour through the application of community empowerment is through educative approach, namely, a series of planned and directed activities systematically implemented by the active participation of the individual, group or community members intended to solve the problems faced by considering the social, economic and cultural issues. This opinion is similar to that of Mikkelsen (2011), says that logic model underlying participatory strategies or community participation in the effort of community empowerment to achieve the goal of development that can be achieved in harmony and the possibility of the incident of conflict between social groups, but this can be mitigated through the pattern of local democracy.

Community participation has brought positive impact to the development, and community participation is also an effective tool to mobilize local resources such as human beings and nature with the aim of implementing certain development program. The extension activity performed is in the form of education intended to equip the team members with good and correct or standard knowledge and positive attitude in health care. The implementation of intervention is one of the cognitive approaches that can help optimalize the role of community members in improving the behavior of pregnant mothers in maternal and child health care.

This is in accordance with the theory saying that knowledge can improve emotional control, improve the independence of the client, increase self-esteem, improve endurance and can help clients to adapt to the problem or a disease that can ultimately improve the quality of life for clients. The forming of behavior started with the cognitive domain which then caused inner response in the forms of attitude toward an object and this response eventually will be in the forms of action or skill. Providing information is a cognitive approach to psychosocial intervention designed to analyze and change the wrong beliefs or values embraced by the client, and also help the client to learn how to use the effective coping strategies (Sarafino, 1994).

The approach to public health behavior change must be preceded by the ability of health workers to master a wide range of socio-cultural background of the people concerned. Social and economic backgrounds have a relationship with the public health behavior (Notoatmodjo, 2005). The daily life of the people of Madina district is still much influenced by the customs, myths, beliefs in supernatural including the antenatal care, giving birth and neonatal care (Daulay, 2010).

Particularly in Mandailing ethnic community, in regulating the system of life, they use the system of Dalian Na Tolu (the three pedestals) the Anak Boru (son in laws of the family of our wife's father and his clan), Kahanggi (our wife's brothers and those who marry our wife's sisters or any son of the family of those with the same clan as our wife's father) and Mora (our wife's father and the male members of the family with the same clan as our father in law). If there is a problem in one family bound in marriage, those entitled to make a decision is the Dalian $\mathrm{Na}$ Tolu (the three pedestals). The culture views a marriage without children as a less fortunate one, that any child born by a married couples is always traditionally blessed in a ceremony known as $\mathrm{Di}$ Pasu-Pasu (Ritonga, 2002).

This is in line with the opinion saying that the indirect causes of maternal and neonate mortality are the community conditions, such as education, the information received, the role of health workers and the socioeconomic and cultural conditions (Pillitteri, 2003). As a health worker, to understand the culture-related community behavior is an important thing in influencing the behavior of pregnant mothers and their family. Mandailing culture is part of core culture of Batak, in which various traditions and cultures in daily health care are still much adopted in the life of Mandailing community (Nasution, 2005).

According to Leiningger in the theory of Transcultural Nursing, health care is an area of cultural science in the process of learning and nursing practice focusing on looking at the difference and similarity between cultures with respect to the care, being healthy and ill is based on human cultural values, beliefs, actions, and the knowledge used to provide nursing care, particularly the culture or cultural integrity to the human being (Tomey and Alligood, 2006).

The culture and tradition adopted by the community can be positive, but there is also a culture that does not comply with the principles of health. As health workers who are responsible to provide education to the community, should be able to correct the perceptions and negative habits that are not conducive to health. This is consistent with the theory of Leininger (1979), Culture Care Diversity and Universality: Transcultural Care, stating that three measures can be adopted in accordance with the culture of patients/community, such as cultural care preservation, accommodation and repatterning (Giger and Davidhizar, 1995).

\section{CONCLUSION}

The implementation of intervention through the establishment of health awareness community team has brought an impact in improving the behaviour of pregnant women in Mandailing Natal (Madina) district community. The variables with significant influence were the knowledge of pregnant mothers $(p=0.001)$ and attitude $(p=0.001)$. Madina district community have their own habit, or tradition and culture in antenatal care, delivery, 
post-partum and neonates. Some of the culture they are practicing positively supports the health but there are also cultural pratices which do not comply with the principles of health.

\section{RECOMMENDATIONS}

1. The government and health workers should involve the community members in the implementation of health program, and pay attention to local culture, knowledge and attitude.

2. Health workers need to understand the cultural background of the local community, the habits and cultural traditions related to the antenatal care, delivery and baby care adopted and practiced by the pregnant mothers and their family that the positive culture or habits can be optimized and the negative culture can be avoided.

\section{Conflict of interest}

Authors have none to declare.
Mikkelsen B (2011). Metode Penelitian Partisipatoris dan Upaya Pemberdayaan; Panduan Bagi Praktis Lapangan. Jakarta: Yayasan Pustaka Obor Indonesia. Available at http://istanaagency.com/sejarah/metode-penelitian-partisipatoris-danupaya-pemberdayaan-panduan-bagi-praktis-lapangan/

Nasution P (2005). Adat budaya mandailing dalam tantangan zaman. Medan: Forkala Prov.Sum.Utara.

Notoatmojo S (2003). Pendidikan Dan Perilaku Kesehatan. Jakarta: Rineka Cipta. Available at: http://nursingcyber.blogspot.com.ng/2013/04/pendidikan-danperilaku-kesehatan.html

Notoatmojo S (2005). Promosi Kesehatan Teori dan Aplikasi (Edisi Revisi). Jakarta: Rineka Cipta. Available at: http://www.bukabuku.com/browses/product/9789790980075/promosikesehatan-teori-dan-aplikasi-(edisi-revisi).html

Pillitteri A (2003). Maternal and Child Health Nursing: Care of the Childbearing and Childrearing Family: 4th (fourth) Edition. Philadelphia: Lippincott Williams \& Wilkins. Available at: http://www.amazon.com/By-Adele-Pillitteri-ChildbearingChildrearing/dp/B001P8AQ78

Ritonga P (2002). Nilai Budaya Dalam Turi-Turian Mandailing Raja Gorga Di Langit Dan Sutan Suasa Di Portibi. hal: 17-44. Medan: PT. Yandir Agung.

Sarafino EP (1994). Health psychology: Biopsychological interactions. $4^{\text {th }}$ Edition, New York: John Wiley.

Saunders G, Wand L, Kreuter MW (2005). Health Program Planning: An Educational and Ecological Approach. Fourth Edition, Me Graw Hill, New York.

Tomey AM, Alligood MR (2006). Nursing Theorist and Their Work. 6th ed. St. Louis, Mo.: Mosby Elsevier, c2006.

\section{REFERENCES}

Bobak IM, Lowdermilk DL, Jensen MD (1995). Maternity nursing. 4th ed. St. Louis: Mosby.

Daulay K (2010). Persepsi Ibu Suku Mandailing tentang Perawatan Bayi Baru Lahir di Kecamatan Sosa Kabupaten Padang Lawas. Fakultas Keperawatan, Universitas Sumatera Utara, 2010. Available at: http://repository.usu.ac.id/bitstream/123456789/20351/7/Cover.pdf

Depkes RI (2002). Pemantauan Pertumbuhan Anak. Direktorat Gizi Masyarakat, Jakarta.

Friedman MM (1998). Family Nursing: Research Theory and Practice. 4th (fourth) Edition. Prentice Hall Professional Technical Reference (September 22, 1998). Stamford, CT: Appleton \& Lange.

Giger JN, Davidhizar RE (1995). Transcultural Nursing: Assessment and Intervention. 2nd ed. Missouri: Mosby Year Book.

Meutia FS (1998). Kehamilan Kelahiran, Perawatan Ibu Dan Bayi Dalam Konteks Budaya. Jakarta. UI press. 